\title{
MAIDEN PEAR TREES GROWTH IN REPLANT SOIL AFTER INOCULATION OF ROOTSTOCKS WITH MYCORRHIZAL INOCULUM
}

\author{
WZROST OKULANTÓW GRUSZY W GLEBIE „REPLANTOWANEJ” \\ PO TRAKTOWANIU PODKŁADEK SZCZEPIONKĄ MIKORYZOWĄ
}

Summary. In the production of fruit trees it is important to set up a nursery always in a new site, alternatively to follow crop rotation rules. It is not always possible due to the size of a farm and production volume. In order to limit the effects of replant soil one can use different procedures before setting up a nursery. Chemical methods, however, must be replaced with non chemical ones due to environmental protection and reduction of production costs. In the experiment conducted in 2009-2012, growth of maiden pear trees of 'Conference' growing on three quince MA, $\mathrm{MC}, \mathrm{S} 1$ rootstocks, cultivated in replant and non-replant soil after the use of mycorrhizal treatment, was compared. The strongest growth of maiden pear trees was obtained on non-replant soil with mycorrhizal and without mycorrhizal treatment of rootstocks. Inoculation of rootstocks influenced positively the height and fresh mass of the root system of maiden pear trees growing on two considered sites. On the other hand, inoculation did not rise the diameter of stem and number of lateral shoots of the maidens. Influence of mycorrhizal treatment of rootstocks on the length of lateral shoots was not obvious. Significantly the best results of maiden pear trees growth, except for the stem diameter, were obtained on MA quince compared to two other types. The mycorrhizal treatment gave better result of percentage obtained by maiden pear trees only in the replant site. The best efficiency of maiden pear trees in nursery production was observed for MA quince rootstock.

Key words: pear, quince, replant soil, mycorrhization, mycorrhizal structures 
Świerczyński, S., Stachowiak, A., Golcz-Polaszewska, M. (2015). Maiden pear trees growth in replant soil after inoculation of rootstocks with mycorrhizal inoculum. Nauka Przyr. Technol., 9, 1, \#3. DOI: 10.17306/J.NPT. 2015.1.3

\section{Introduction}

Intensification of many agricultural cultivations causes that the same species appear on the same plots in the crop rotation cycles in much shorter periods of time. The consequence of such activities can be a disease phenomenon, which is more and more popular, especially in orchards and nurseries. A lot of research has been carried out to limit the consequences of this phenomenon in orchards (Bechmer et al., 2003; Kowalik et al., 1998; Merwin and Byard, 2001; Reginato et al., 2008; Szczygieł and Zepp, 1998; Tustin et al., 2008; Zydlik, 2004), but fewer studies concern nurseries (Porębski et al., 2003; Simeone et al., 2006). Recently, studies on the use of mycorrhizal inoculum to limit the 'disease' have been carried out (Caruso et al., 1989; Catska, 1994; Catska and Taube-Baab, 1994; Druzic-Orlic et al., 2008; Monticelli et al., 2000; Rutto and Mizutani, 2006).

Mycorrhizal inoculums, so far, have been used in an apple trees nursery (Raj and Sharma, 2009). Inoculation of plants affected the increase in length of lateral shoots and roots of maiden apple trees. Also Druzic-Orlic et al. (2008) used different mycorrhizal inoculums while planting the rootstocks into the nursery ground obtaining a better growth of plants in comparison with rootstocks not treated with the mycorrhizal inoculum.

In the experiments that have been carried out so far in an orchard the use of mycorrhizal inoculum improved the growth of apple and peach trees (Bingye and Shengrui, 1998; Utkhede et al., 1992). There are some opinions, however, that mycorrhization does not influence positively the growth of apple trees in an orchard (Bennewitz and Hlusek, 2006), as well as the seedlings of peach trees (Rutto and Mizutani, 2005, 2006).

The aim of the present studies was the evaluation of influence of mycorrhizal inoculum on the growth of maiden pear trees on three quince rootstocks cultivated in a replant soil and non-replant soil.

\section{Material and methods}

The studies were carried out at the Agricultural Experimental Station in Baranowo belonging to the Poznan University of Life Sciences, in 2009-2012. The experiment was set up in random sub-blocks design, in four replications with 50 rootstocks in $90 \times 30$ $\mathrm{cm}$ spacing planted on one plot. In one part of the experiment MA, MC and S1 quince rootstocks were planted in early spring on the site occupied previously by a nursery for three years, and the other site did not have such a record. All the rootstocks had a diameter of 7-8 $\mathrm{mm}$. Half of the rootstocks was treated with mycorrhizal inoculum of 'Suplo' company during the planting process, the rest was a control. Before using the inoculum containing live mycelium (500 ml inoculum, dry weight $36.3 \mathrm{~g}$ ) it was mixed for $15 \mathrm{~s}$ with $500 \mathrm{ml}$ of distilled water and a special gel was added. For one rootstock approximately $20 \mathrm{ml}$ of suspension was used. The gel was used also in control plants. Special separating, protective zone of $5.4 \mathrm{~m}$ was established between the inoculated and non inoculated plants. 
Świerczyński, S., Stachowiak, A., Golcz-Polaszewska, M. (2015). Maiden pear trees growth in replant soil after inoculation of rootstocks with mycorrhizal inoculum. Nauka Przyr. Technol., 9, 1, \#3. DOI: 10.17306/J.NPT. 2015.1.3

The experiment was located on loam soil belonging to fourth valuation class. Protection and care of growing plants were carried out in accordance with the latest recommendations for a rootstock nursery. During the research no herbicides were used and the nursery was mechanically and, if needed, manually weeded. Nitrogen fertilizer was applied three times in a cumulative dose of $90 \mathrm{~kg} \cdot \mathrm{ha}^{-1}$. Rootstock plots were not watered. The rootstocks were budded with 'Conference' in the first decade of August using 'letter T' budding method on the height of $10 \mathrm{~cm}$ above the ground. After vegetation period, at the end of November, all obtained maiden pear trees were measured. The measurements of height $(\mathrm{cm})$ and diameter $(\mathrm{mm}) 20 \mathrm{~cm}$ above the ground level and length of lateral shoots $(\mathrm{cm})$ of 15 maiden pear trees per plot were carried out and number of lateral shoots was calculated as well. After taking out from the ground fresh mass of the root system of five maiden trees per plot was weighed, too $(\mathrm{g})$.

In order to confirm the presence of mycorrhizal fungi, root samples of rootstocks treated and not treated with mycorrhizal inoculums were taken. They were coloured with $0.05 \%$ trypan blue in lactic acid. Later they were discoloured and the presence of mycorrhizal structures was evaluated under a microscope. The photographs are placed at the end of this paper.

The statistical analysis of the obtained data was carried out with the help of STAT program, with the application of two-factor variance analysis using Duncan's test, with probability level $\alpha=0.05$. Results shown in tables are mean values of three successive years of studies.

\section{Results and discussion}

The height of maiden pear trees was differentiated and depended on the used type of quince rootstocks, soil conditions and mycorrhizal treatment. The highest plants were obtained on a plot with non-replant soil with mycorrhiza. Maiden trees lower than the mentioned ones grew on non-replant soil without mycorrhiza. Maiden pear trees cultivated in replant soil were higher after the use of mycorrhizal inoculum compared with non inoculated ones. The lowest plants were obtained on MC quince rootstock. Significantly higher than the mentioned ones were maiden pear trees on quince S1, and the highest on quince MA (Table 1).

The diameters of maiden pear trees grown on non-replant soil with mycorrhizal inoculum were the same as on non-replant soil without mycorrhizal inoculum. Also maiden pear trees cultivated in replant soil after the application of mycorrhizal inoculum did not differ from non inoculated ones. Used type of quince did not have any influence on the diameter of stems of maiden pear trees (Table 2).

The length of lateral shoots of maiden pear trees was significantly different. The best results were noted for maiden pear trees growing on plots with non-replant soil without mycorrhiza. The maiden pear trees cultivated on replant soil with mycorrhiza had a bigger sum of long shoots than those without mycorrhiza. The length of lateral shoots of maiden pear trees growing on MA quince was higher than of the two other rootstocks (Table 3). 
Świerczyński, S., Stachowiak, A., Golcz-Polaszewska, M. (2015). Maiden pear trees growth in replant soil after inoculation of rootstocks with mycorrhizal inoculum. Nauka Przyr. Technol., 9, 1, \#3. DOI: 10.17306/J.NPT. 2015.1.3

Table 1. Height of maiden pear trees depending on the type of quince and soil Tabela 1. Wysokość okulantów gruszy w zależności od typu pigwy i gleby

\begin{tabular}{|l|c|c|c|c|c|}
\hline $\begin{array}{c}\text { Type of } \\
\text { quince } \\
\text { Typ pigwy }\end{array}$ & $\begin{array}{c}\text { Non replant soil } \\
\text { with mycorrhizal } \\
\text { inoculum } \\
\text { Gleba niereplanto- } \\
\text { wana ze szczepion- } \\
\text { ką mikoryzową }\end{array}$ & $\begin{array}{c}\text { Non replant soil } \\
\text { without mycorrhi- } \\
\text { zal inoculum } \\
\text { Gleba niereplanto- } \\
\text { wana bez szcz- } \\
\text { pionki mikoryzo- } \\
\text { wej }\end{array}$ & $\begin{array}{c}\text { Replant soil } \\
\text { with mycorrhizal } \\
\text { inoculum } \\
\text { Gleba replantowana } \\
\text { ze szczepionką } \\
\text { mikoryzową }\end{array}$ & $\begin{array}{c}\text { Replant soil with- } \\
\text { out mycorrhizal } \\
\text { inoculum } \\
\text { Gleba replantowana } \\
\text { bez szczepionki } \\
\text { mikoryzowej }\end{array}$ & $\begin{array}{c}\text { Mean } \\
\text { Srednia }\end{array}$ \\
\hline MA & $132.4 \mathrm{e}$ & $123.8 \mathrm{de}$ & $96.4 \mathrm{bc}$ & $92.9 \mathrm{bc}$ & $111.4 \mathrm{c}$ \\
MC & $119.4 \mathrm{~d}$ & $115.7 \mathrm{~d}$ & $85.2 \mathrm{~b}$ & $69.3 \mathrm{a}$ & $97.4 \mathrm{a}$ \\
S1 & $120.3 \mathrm{~d}$ & $114.0 \mathrm{~d}$ & $97.1 \mathrm{c}$ & $92.6 \mathrm{bc}$ & $106.0 \mathrm{~b}$ \\
\hline $\begin{array}{l}\text { Mean } \\
\text { Średnia }\end{array}$ & $124.0 \mathrm{~d}$ & $117.8 \mathrm{c}$ & $92.9 \mathrm{~b}$ & $84.9 \mathrm{a}$ & \\
\hline
\end{tabular}

Means in rows and in columns followed by the same letters are not significantly different at the level of $\alpha=0.05$. Średnie oznaczone w rzędach i kolumnach tymi samymi literami nie różnią się istotnie na poziomie $\alpha=0,05$.

Table 2. Diameter of maiden pear trees depending on the type of quince and soil Tabela 2. Średnica okulantów gruszy w zależności od typu pigwy i gleby

\begin{tabular}{|l|c|c|c|c|c|}
\hline $\begin{array}{c}\text { Type of } \\
\text { quince } \\
\text { Typ pigwy }\end{array}$ & $\begin{array}{c}\text { Non replant soil } \\
\text { with mycorrhizal } \\
\text { inoculum } \\
\text { Gleba niereplanto- } \\
\text { wana ze szczepion- } \\
\text { ką mikoryzową }\end{array}$ & $\begin{array}{c}\text { Non replant soil } \\
\text { without mycorrhi- } \\
\text { zal inoculum } \\
\text { Gleba niereplanto- } \\
\text { wana bez szcze- } \\
\text { pionki mikoryzo- } \\
\text { wej }\end{array}$ & $\begin{array}{c}\text { Replant soil } \\
\text { with mycorrhizal } \\
\text { inoculum } \\
\text { Gleba replantowana } \\
\text { ze szczepionką } \\
\text { mikoryzową }\end{array}$ & $\begin{array}{c}\text { Replant soil with- } \\
\text { out mycorrhizal } \\
\text { inoculum } \\
\text { Gleba replantowana } \\
\text { bez szczepionki } \\
\text { mikoryzowej }\end{array}$ & $\begin{array}{c}\text { Mean } \\
\text { Srednia }\end{array}$ \\
\hline MA & $13.1 \mathrm{~cd}$ & $13.9 \mathrm{~d}$ & $10.1 \mathrm{ab}$ & $10.3 \mathrm{ab}$ & $11.8 \mathrm{a}$ \\
MC & $12.6 \mathrm{~cd}$ & $12.5 \mathrm{c}$ & $10.5 \mathrm{ab}$ & $10.3 \mathrm{ab}$ & $11.5 \mathrm{a}$ \\
S1 & $12.4 \mathrm{c}$ & $13.2 \mathrm{~cd}$ & $10.7 \mathrm{~b}$ & $10.3 \mathrm{a}$ & $1.4 \mathrm{a}$ \\
\hline $\begin{array}{l}\text { Mean } \\
\text { Średnia }\end{array}$ & $12.7 \mathrm{~b}$ & $10.0 \mathrm{a}$ & & 1.4 \\
\hline
\end{tabular}

Means in rows and in columns followed by the same letters are not significantly different at the level of $\alpha=0.05$. Średnie oznaczone w rzędach i kolumnach tymi samymi literami nie różnią się istotnie na poziomie $\alpha=0,05$.

The number of branches obtained on non-replant soil was higher than of those obtained on 'replant' soil. Maiden pear trees grown on MA quince had significantly bigger number of lateral shoots than two other rootstocks (Table 4).

Application of mycorrhizal inoculum influenced fresh mass of the root system of maiden pear trees better on plots with replant and non-replant soil. Bigger mass of roots was obtained on MA rootstock compared with MC and S1 (Table 5). 
Świerczyński, S., Stachowiak, A., Golcz-Polaszewska, M. (2015). Maiden pear trees growth in replant soil after inoculation of rootstocks with mycorrhizal inoculum. Nauka Przyr. Technol., 9, 1, \#3. DOI: 10.17306/J.NPT. 2015.1.3

Table 3. Sum of long lateral shoots of maiden pear trees depending on the type of quince and soil Tabela 3. Suma długości pędów bocznych okulantów gruszy w zależności od typu pigwy i gleby

\begin{tabular}{|c|c|c|c|c|c|}
\hline $\begin{array}{l}\text { Type of } \\
\text { quince } \\
\text { Typ pigwy }\end{array}$ & $\begin{array}{c}\text { Non replant soil } \\
\text { with mycorrhizal } \\
\text { inoculum } \\
\text { Gleba niereplanto- } \\
\text { wana ze szczepion- } \\
\text { ką mikoryzową }\end{array}$ & $\begin{array}{l}\text { Non replant soil } \\
\text { without mycorrhi- } \\
\text { zal inoculum } \\
\text { Gleba niereplanto- } \\
\text { wana bez szcze- } \\
\text { pionki mikoryzo- } \\
\text { wej }\end{array}$ & $\begin{array}{c}\text { Replant soil } \\
\text { with mycorrhizal } \\
\text { inoculum } \\
\text { Gleba replantowana } \\
\text { ze szczepionką } \\
\text { mikoryzową }\end{array}$ & $\begin{array}{l}\text { Replant soil with- } \\
\text { out mycorrhizal } \\
\text { inoculum } \\
\text { Gleba replantowana } \\
\text { bez szczepionki } \\
\text { mikoryzowej }\end{array}$ & $\begin{array}{l}\text { Mean } \\
\text { Średnia }\end{array}$ \\
\hline MA & $37.7 \mathrm{~d}$ & $66.8 \mathrm{e}$ & $15.2 \mathrm{bc}$ & $10.5 \mathrm{~b}$ & $32.5 \mathrm{~b}$ \\
\hline $\mathrm{MC}$ & $16.3 \mathrm{bc}$ & $14.4 \mathrm{bc}$ & $13.9 \mathrm{bc}$ & $1.7 \mathrm{a}$ & $11.5 \mathrm{a}$ \\
\hline S1 & $18.5 \mathrm{c}$ & $18.7 \mathrm{c}$ & $11.2 \mathrm{~b}$ & $0.4 \mathrm{a}$ & $12.2 \mathrm{a}$ \\
\hline $\begin{array}{l}\text { Mean } \\
\text { Średnia }\end{array}$ & $24.1 \mathrm{c}$ & $33.3 \mathrm{~d}$ & $13.4 \mathrm{~b}$ & $4.2 \mathrm{a}$ & \\
\hline
\end{tabular}

Means in rows and in columns followed by the same letters are not significantly different at the level of $\alpha=0.05$. Średnie oznaczone w rzędach i kolumnach tymi samymi literami nie różnią się istotnie na poziomie $\alpha=0,05$.

Table 4. Number of lateral shoots of maiden pear trees depending on the type of quince and soil Tabela 4. Liczba pędów bocznych okulantów gruszy w zależności od typu pigwy i gleby

\begin{tabular}{|l|c|c|c|c|c|}
\hline $\begin{array}{c}\text { Type of } \\
\text { quince } \\
\text { Typ pigwy }\end{array}$ & $\begin{array}{c}\text { Non replant soil } \\
\text { with mycorrhizal } \\
\text { inoculum } \\
\text { Gleba niereplanto- } \\
\text { wana ze szczepion- } \\
\text { ką mikoryzową }\end{array}$ & $\begin{array}{c}\text { Non replant soil } \\
\text { without mycorrhi- } \\
\text { zal inoculum } \\
\text { Gleba niereplanto- } \\
\text { wana bez szcze- } \\
\text { pionki mikoryzo- } \\
\text { wej }\end{array}$ & $\begin{array}{c}\text { Replant soil } \\
\text { with mycorrhizal } \\
\text { inoculum } \\
\text { Gleba replantowana } \\
\text { ze szczepionką } \\
\text { mikoryzową }\end{array}$ & $\begin{array}{c}\text { Replant soil with- } \\
\text { out mycorrhizal } \\
\text { inoculum } \\
\text { Gleba replantowana } \\
\text { bez szczepionki } \\
\text { mikoryzowej }\end{array}$ & $\begin{array}{c}\text { Mean } \\
\text { Srednia }\end{array}$ \\
\hline MA & $1.6 \mathrm{~b}$ & $3.2 \mathrm{c}$ & $0.7 \mathrm{ab}$ & $0.4 \mathrm{ab}$ & $1.5 \mathrm{~b}$ \\
$\mathrm{MC}$ & $0.9 \mathrm{ab}$ & $0.8 \mathrm{ab}$ & $0.6 \mathrm{ab}$ & $0.1 \mathrm{a}$ & $0.6 \mathrm{a}$ \\
S1 & $1.0 \mathrm{ab}$ & $1.0 \mathrm{ab}$ & $0.5 \mathrm{ab}$ & $0.1 \mathrm{a}$ & $0.7 \mathrm{a}$ \\
\hline $\begin{array}{l}\text { Mean } \\
\text { Średnia }\end{array}$ & $1.0 \mathrm{~b}$ & $0.6 \mathrm{a}$ & $0.2 \mathrm{~b}$ & \\
\hline
\end{tabular}

Means in rows and in columns followed by the same letters are not significantly different at the level of $\alpha=0.05$. Średnie oznaczone w rzędach i kolumnach tymi samymi literami nie różnią się istotnie na poziomie $\alpha=0,05$.

Mycorrhizal treatment gave better results of the percentage of the obtained maiden pear trees only in replant site. The best efficiency of maiden pear trees in nursery production was observed for MA quince (Table 6).

Presence of mycorrhizal fungi on the root system of quince was confirmed after taking pictures of microscopic preparations (Fig. 1). Mycorrhizal structures were not observed on the roots of control rootstocks. 
Świerczyński, S., Stachowiak, A., Golcz-Polaszewska, M. (2015). Maiden pear trees growth in replant soil after inoculation of rootstocks with mycorrhizal inoculum. Nauka Przyr. Technol., 9, 1, \#3. DOI: 10.17306/J.NPT. 2015.1 .3

Table 5. Fresh mass of root system of maiden pear trees depending on the type of quince and soil Tabela 5. Świeża masa systemu korzeniowego okulantów gruszy w zależności od typu pigwy i gleby

\begin{tabular}{|c|c|c|c|c|c|}
\hline $\begin{array}{l}\text { Type of } \\
\text { quince } \\
\text { Typ pigwy }\end{array}$ & $\begin{array}{c}\text { Non replant soil } \\
\text { with mycorrhizal } \\
\text { inoculum } \\
\text { Gleba niereplan- } \\
\text { towana ze szcze- } \\
\text { pionką mikoryzową }\end{array}$ & $\begin{array}{l}\text { Non replant soil } \\
\text { without mycorrhi- } \\
\text { zal inoculum } \\
\text { Gleba niereplanto- } \\
\text { wana bez szcze- } \\
\text { pionki mikoryzo- } \\
\text { wej }\end{array}$ & $\begin{array}{c}\text { Replant soil } \\
\text { with mycorrhizal } \\
\text { inoculum } \\
\text { Gleba replantowana } \\
\text { ze szczepionką } \\
\text { mikoryzową }\end{array}$ & $\begin{array}{c}\text { Replant soil with- } \\
\text { out mycorrhizal } \\
\text { inoculum } \\
\text { Gleba replantowana } \\
\text { bez szczepionki } \\
\text { mikoryzowej }\end{array}$ & $\begin{array}{c}\text { Mean } \\
\text { Średnia }\end{array}$ \\
\hline MA & $149.3 \mathrm{~g}$ & $138.5 \mathrm{f}$ & $125.5 \mathrm{~d}$ & $112.6 \mathrm{bc}$ & $131.5 \mathrm{~b}$ \\
\hline $\mathrm{MC}$ & $134.8 \mathrm{e}-\mathrm{f}$ & $127.7 \mathrm{de}$ & $110.0 \mathrm{bc}$ & $98.5 \mathrm{a}$ & $117.8 \mathrm{a}$ \\
\hline S1 & 136.7 e-f & $129.8 \mathrm{~d}-\mathrm{f}$ & $115.4 \mathrm{c}$ & $105.6 \mathrm{ab}$ & $121.9 \mathrm{a}$ \\
\hline $\begin{array}{l}\text { Mean } \\
\text { Średnia }\end{array}$ & $140.3 \mathrm{~d}$ & $132.0 \mathrm{c}$ & $117.0 \mathrm{~b}$ & $105.6 \mathrm{a}$ & \\
\hline
\end{tabular}

Means in rows and in columns followed by the same letters are not significantly different at the level of $\alpha=0.05$. Średnie oznaczone w rzędach i kolumnach tymi samymi literami nie różnią się istotnie na poziomie $\alpha=0,05$.

Table 6. Percentage of obtained maiden pear trees depending on the type of quince and soil Tabela 6. Procent otrzymanych okulantów gruszy w zależności od typu pigwy i gleby

\begin{tabular}{|c|c|c|c|c|c|}
\hline $\begin{array}{l}\text { Type of } \\
\text { quince } \\
\text { Typ pigwy }\end{array}$ & $\begin{array}{l}\text { Non replant soil } \\
\text { with mycorrhizal } \\
\text { inoculum } \\
\text { Gleba niereplanto- } \\
\text { wana ze szczepion- } \\
\text { ką mikoryzową }\end{array}$ & $\begin{array}{l}\text { Non replant soil } \\
\text { without mycorrhi- } \\
\text { zal inoculum } \\
\text { Gleba niereplanto- } \\
\text { wana bez szcze- } \\
\text { pionki mikoryzo- } \\
\text { wej }\end{array}$ & $\begin{array}{c}\text { Replant soil } \\
\text { with mycorrhizal } \\
\text { inoculum } \\
\text { Gleba replantowana } \\
\text { ze szczepionką } \\
\text { mikoryzową }\end{array}$ & \begin{tabular}{|} 
Replant soil with- \\
out mycorrhizal \\
inoculum \\
Gleba replantowana \\
bez szczepionki \\
mikoryzowej
\end{tabular} & $\begin{array}{l}\text { Mean } \\
\text { Średnia }\end{array}$ \\
\hline MA & $72.2 \mathrm{e}$ & $71.6 \mathrm{e}$ & $67.1 \mathrm{~d}$ & $66.0 \mathrm{~cd}$ & $69.3 \mathrm{c}$ \\
\hline $\mathrm{MC}$ & $66.6 \mathrm{~cd}$ & $63.3 \mathrm{bc}$ & $59.8 \mathrm{ab}$ & $57.8 \mathrm{a}$ & $61.9 \mathrm{a}$ \\
\hline S1 & $67.5 \mathrm{~d}$ & $66.7 \mathrm{~cd}$ & $69.0 \mathrm{de}$ & $61.4 \mathrm{ab}$ & $66.2 \mathrm{~b}$ \\
\hline $\begin{array}{l}\text { Mean } \\
\text { Średnia }\end{array}$ & $68.8 \mathrm{c}$ & $67.3 \mathrm{bc}$ & $65.4 \mathrm{~b}$ & $61.8 \mathrm{a}$ & \\
\hline
\end{tabular}

Means in rows and in columns followed by the same letters are not significantly different at the level of $\alpha=0.05$. Średnie oznaczone w rzędach i kolumnach tymi samymi literami nie różnią się istotnie na poziomie $\alpha=0,05$.

In the considered experiment the height and fresh mass of the root system of maiden pear trees growing on non-replant and replant soil after mycorrhization was significantly bigger. On the other hand, the diameter and the number of lateral shoots did not change significantly after the use of mycorrhization of the rootstocks on both plots. As far as the sum of lengths of lateral shoots is concerned the obtained results were not univocal. Maiden pear trees cultivated on non-replant soil had longer lateral shoots without mycorrhizal inoculation, and on the plot with replant soil after the mycorrhizal inoculation. 
Świerczyński, S., Stachowiak, A., Golcz-Polaszewska, M. (2015). Maiden pear trees growth in replant soil after inoculation of rootstocks with mycorrhizal inoculum. Nauka Przyr. Technol., 9, 1, \#3. DOI: 10.17306/J.NPT. 2015.1.3

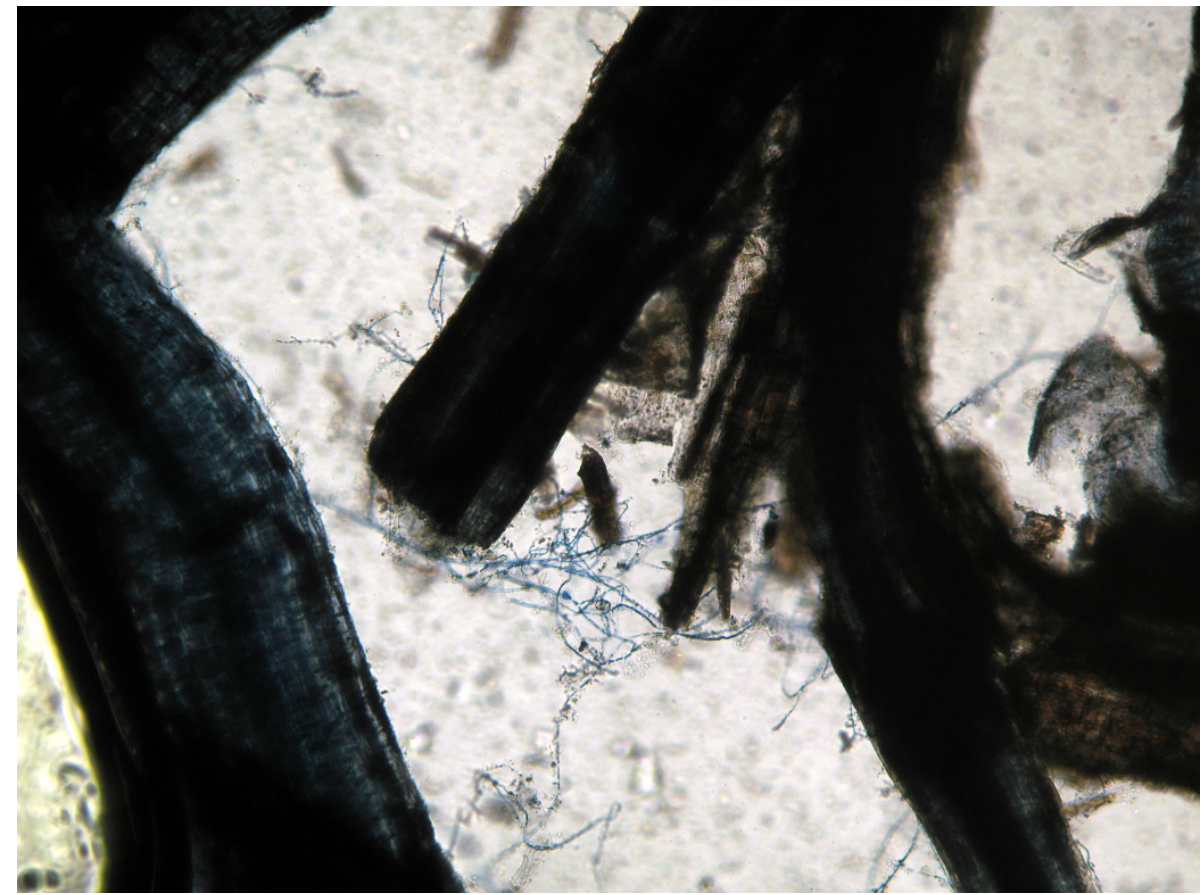

Fig. 1. Fragment of the S1 quince root coming from rootstocks with mycorrhizal fungal hyphae

Rys. 1. Fragment korzenia pigwy S1 pochodzący z podkładek ze strzępkami grzybni mikoryzowej

In the experiment carried out by Raj and Sharma (2009) the presence of mycorrhizal fungi increased the length of shoots and roots of maiden apple trees in a nursery. In an earlier observation (Świerczyński and Stachowiak, 2012) sweet cherry maiden trees growth obtained in no replant soil after used of mycorrhizal inoculum increasing of diameter and fresh mass of maiden trees. Utkhede et al. (1992) confirmed the fact that the use of mycorrhizal inoculum increased the number of lateral shoots of apple trees growing in replant soil. Also in the studies carried out by Catska and Taube-Baab (1994) inoculation of apple trees seedlings with mycorrhizal fungi improved their growth in replant soil. Similarly Bingye and Shengrui (1998), as well as Rutto and Mizutani (2006) obtained a better growth of peach trees seedlings after mycorrhization in replant soil. Also Druzic-Orlic et al. (2008) having planted GF 655/2 and Gisella 5 rootstocks into non-replant soil noticed a better growth of plants after inoculation in comparison with the rootstocks not inoculated with micorrhizal inoculum.

However, presence of mycorrhizal fungi in plants is strictly connected with biological and physical properties of the soil (Schreiner, 2003). In the present experiment the soil was concise and periodically very watery, which did not support the growth of mycorrhizal fungi. On the other hand it could stimulate the development of the 'disease' 
Świerczyński, S., Stachowiak, A., Golcz-Polaszewska, M. (2015). Maiden pear trees growth in replant soil after inoculation of rootstocks with mycorrhizal inoculum. Nauka Przyr. Technol., 9, 1, \#3. DOI: 10.17306/J.NPT. 2015.1 .3

causing microorganisms. It seems that soil sickness has a negative impact on plant metabolism and limits the capacity of the host plant to support the mycorrhizal symbiosis (Rutto and Mizutani, 2006).

A factor that differentiated the growth of maiden pear trees was also the quince type. Significantly higher and better branched maiden pear trees were obtained on MA quince. Also Fischer $(2005,2007)$ noticed a better growth of maiden pear trees of 'Conference' on MA quince in comparison with S1 quince.

On the basis of the conducted experiment it was found that inoculation of rootstocks with mycorrhizal inoculum improved the growth of maiden pear trees growing in replant and non-replant soil.

\section{Conclusions}

1. The best growth of maiden pear trees was obtained in plots with non-replant soil.

2. The mycorrhizal inoculum had a positive influence on height, fresh mass of root system and percentage obtained of maiden pear trees growing in replant and non-replant soil.

3. The maiden pear trees growing in non-replant soil with mycorrhizal inoculum had a lower total length of lateral shoots than without mycorrhizal treatment.

4. The strongest growth and better efficiency of maiden pear trees was observed on MA quince rootstock.

\section{References}

Bechmer, S., Prinzio, A., Irisarri, J., Streibeck, G. (2003). Subsoiling techniques in orchard replanting. Agrociencia, 19, 31-36.

Bennewitz, E., Hlusek, J. (2006). Effect of the application of two biopreparations on the nutritional status, vegetative and generative behaviour of 'Jonagold' apple trees. Acta Hortic. (Leuven), 721, 129-136.

Bingye, X., Shengrui, Y. (1998). Studies on replant problems of apple and peach. Acta Hortic. (Leuven), 477, 83-88.

Caruso, F. L., Neubauer, B. F., Begin, M. D. (1989). A histological study of apple roots affected by replant disease. Can. J. Bot., 67, 742-749.

Catska, V. (1994). Interrelationships between vesicular-arbuscular mycorrhiza and rhizosphere microflora in apple replant disease. Biol. Plant. (Prague), 36, 99-104.

Catska, V., Taube-Baab, H. (1994). Biological control of replant problems. Acta Hortic. (Leuven), 363, 115-120.

Druzic-Orlic, J., Cmelik, Z., Redzepovic, S. (2008). Influence of arbuscular mycorrhizal fungi on fruit rootstocks. Acta Hortic. (Leuven), 767, 393-396.

Fischer, M. (2005). Ergebnisse des Naumburg-Pillnitzer Birnenunterlagenzuchtprogrammes. Erwerbs-Obstbau, 47, 1, 6-11.

Fischer, M. (2007). New pear rootstocks from Dresden-Pillnitz. Acta Hortic. (Leuven), 732, 239 -245 . 
Świerczyński, S., Stachowiak, A., Golcz-Polaszewska, M. (2015). Maiden pear trees growth in replant soil after inoculation of rootstocks with mycorrhizal inoculum. Nauka Przyr. Technol., 9, 1, \#3. DOI: 10.17306/J.NPT. 2015.1 .3

Kowalik, M., Poniedziałek, W., Porębski, S. (1998). Wykorzystanie humusu i torfu w ograniczeniu choroby replantacji w sadzie jabłoniowym. Zesz. Nauk. AR Krak., 333, Ses. Nauk., 57, 479-484.

Merwin, I. A., Byard, R. (2001). Developing an integrated program for diagnosis and control of replant problems in New York. N. Y. Fruit Q., 9, 1, 11-15.

Monticelli, S., Puppi, G., Damiano, C. (2000). Effects of in vivo mycorrhization on micropropagated fruit tree rootstocks. Appl. Soil Ecol., 15, 2, 105-111.

Porębski, S., Poniedziałek, W., Rzeźnicka, B. (2003). Effect of organic matter, ammonium phosphate, and Captan on growth and quality of one-year-old apple trees. Folia Hortic., 15, 2, $151-157$.

Raj, H., Sharma, S. D. (2009). Integration of soil solarization and chemical sterilization with beneficial microorganisms for the control of white root and growth of nursery apple. Sci. Hortic., 119, 126-131.

Reginato, G., Cordova, C., Mauro, C. (2008). Evaluation of rootstock and management practices to avoid cherry replant disease in Chile. Acta Hortic. (Leuven), 795, 357-362.

Rutto, K. L., Mizutani, F. (2005). Replant soil and peach detritus inhibit arbuscular mycorrhizal activity and retard peach seedling growth. Bull. Exp. Farm Fac. Agric. Ehime Univ., 27, 1-9.

Rutto, K. L., Mizutani, F. (2006). Peach seedling growth in replant and non-replant soils after inoculation with arbuscular mycorrhizal fungi. Soil Biol. Biochem., 38, 9, 2536-2542.

Schreiner, R. P. (2003). Mycorrhizal colonization of grapevine rootstocks under field conditions. Am. J. Enol. Vitic., 54, 143-149.

Simeone, A. M., Scortichini, M., Di Basilio, L., Fideghelli, C., Di Vito, M. (2006). Growing behaviour of peach rootstocks in two 'old' and 'new' soils. Acta Hortic. (Leuven), 713, 321-326 .

Szczygiel, A., Zepp, A. L. (1998). Results of pot experiments on control of apple replant disease. Acta Hortic. (Leuven), 477, 103-106.

Świerczyński, S., Stachowiak, A. (2012). Usefulness of four rootstocks and mycorrhization treatment in production of sweet cherry maiden trees in a nursery. Acta Sci. Pol. Hort. Cult., 11, 2, $149-159$.

Tustin, D. S., Horner, I., Breen, K., Dayatilake, D., Bigwood, E. (2008). Growth responses of young apple plants induced by soil remediation treatments for specific apple replant disease. Acta Hortic. (Leuven), 772, 407-411.

Utkhede, R. S., Li, T. S. C., Smith, E. M. (1992). The effect of Glomus mosseae and enterobacter on apple seedlings grown in apple replant disease soil. J. Phytopathol. (Berl.), 135, 4, 281-288 .

Zydlik, Z. (2004). Effect of locality on the microbiological condition of soil from replanted apple orchard. Folia Univ. Agric. Stetin., 240, Agric., 96, 219-224.

\section{WZROST OKULANTÓW GRUSZY W GLEBIE „REPLANTOWANEJ” PO TRAKTOWANIU PODKŁADEK SZCZEPIONKĄ MIKORYZOWĄ}

Streszczenie. W produkcji drzewek owocowych ważne jest, aby każdorazowo zakładać szkółkę na nowym stanowisku, ewentualnie przestrzegać właściwego zmianowania. Jednak nie zawsze jest to możliwe ze względu na powierzchnię gospodarstwa oraz wielkość produkcji. W celu ograniczenia skutków zjawiska „zmęczenia gleby” można przed założeniem szkółki stosować różnego rodzaju zabiegi, przy czym metody chemiczne muszą być zastępowane metodami niechemicznymi z uwagi na konieczność ochrony środowiska i ograniczania kosztów produkcji. W doświad- 
Świerczyński, S., Stachowiak, A., Golcz-Polaszewska, M. (2015). Maiden pear trees growth in replant soil after inoculation of rootstocks with mycorrhizal inoculum. Nauka Przyr. Technol., 9, 1, \#3. DOI: 10.17306/J.NPT. 2015.1 .3

czeniu przeprowadzonym w latach 2009-2012 porównano wzrost okulantów gruszy w glebie „replantowanej” i „niereplantowanej” po zabiegu mikoryzacji podkładek pigwy MA, MC i S1. Najsilniejszy wzrost okulantów uzyskano na stanowisku z glebą „niereplantowaną” po zastosowaniu zabiegu mikoryzacji podkładek i bez niego. Inokulacja podkładek wpłynęła pozytywnie na wysokość i świeżą masę systemu korzeniowego okulantów gruszy rosnących na obu rozpatrywanych stanowiskach, jednak nie zwiększyła średnicy pnia ani liczby pędów bocznych okulantów. Wpływ zabiegu mikoryzacji podkładek na długość pędów bocznych był niejednoznaczny. Istotnie najlepsze wyniki wzrostu okulantów gruszy - z wyjątkiem średnicy pnia - uzyskano na podkładce pigwy MA. Zabieg mikoryzacji zwiększył procent okulantów gruszy tylko na stanowisku replantowanym. Najlepszą wydajność okulantów gruszy w produkcji szkółkarskiej zaobserwowano po zastosowaniu podkładki MA.

Słowa kluczowe: grusza, pigwa, gleba „replantowana”, mikoryzacja, struktury mikoryzowe

Corresponding address - Adres do korespondencji:

Stawomir Świerczyński, Katedra Dendrologii i Szkółkarstwa, Uniwersytet Przyrodniczy w Poznaniu, Baranowo, ul. Szamotulska 28,62-081 Przeźmierowo,Poland, e-mail: okulant@gmail.com

Accepted for publication - Zaakceptowano do opublikowania:

25.09.2014

For citation - Do cytowania:

Świerczyński, S., Stachowiak, A., Golcz-Polaszewska, M. (2015). Maiden pear trees growth in replant soil after inoculation of rootstocks with mycorrhizal inoculum. Nauka Przyr. Technol., 9, 1, \#3. DOI: 10.17306/J.NPT.2015.1.3 